\title{
KEBIJAKAN DAN PENGELOLAAN RISIKO KREDIT PERBANKAN (STUDI PADA SALAH SATU KANTOR WILAYAH DAN KANTOR CABANG BANK KONVENSIONAL)
}

\author{
Yanuar Andrianto \\ Moeljadi \\ Andarwati \\ Fakultas Ekonomi dan Bisnis \\ Universitas Brawijaya
}

\begin{abstract}
Perbankan di Indonesia memiliki peranan penting sebagai penggerak perekomian. Aktivitas penyaluran kredit merupakan sumber pendapatan utama bank dan merupakan menjadi risiko bisnis terbesar. Penyaluran kredit modal kerja dan kredit investasi mendukung aktivitas bisnis yang sehat dalam percepatan ekonomi global. Ditengah gencarnya penyaluran kredit bagi dunia usaha, sebagai lembaga keuangan yang diawasi oleh Otoritas Jasa Keungan (OJK), perbankan harus menjaga kualitas kredit yang disalurkan kepada masyakat sesuai peraturan yang ditetapkan oleh Bank Indonesia. Hal ini berguna agar pertumbuhan kredit prebankan terhindar dari risiko kredit bermasalah. Studi ini bertujuan untuk menganalisis implementasi kebijakan kredit modal kerja dan kredit investasi, serta pengelolaan dan pengawasan risiko kredit. Peneliti menggunakan pendekatan kualitatif untuk melakukan penelusuran pada salah satu bank konvensional terbesar di Indonesia. Studi kasus yang diambil adalah pada salah satu kantor wilayah yang membawahi puluhan kantor cabang. Penetapan lokasi dan informan menggunakan teknik purposive. Penggalian data dilakukan dengan document review dan melalui in-depth interview dilakukan penelusuran mendalam. In-depth interview terhadap 12 informan terdiri dari pelaksana kredit, pelaksana administrasi kredit, pelaksana analisis risiko, pejabat kredit, dan pihak Bank Indonesia. Data dianalisis menggunakan analisis isi (content analysis). Temuan pada penelitian ini adalah bahwa kebijakan dan peraturan kredit yang mengutamakan prinsip kehati-hatian (prudent) dimanifestasikan pada prinsip pokok pemberian kredit, tata cara penilaian kualitas kredit, serta profesionalisme dan integritas pejabat perkreditan. Kebijakan dan peraturan tersebut bertujuan untuk mendapatkan kejelasan informasi (symmetric information) profil risiko debitur. Pendekatan pencegahan risiko kredit dilakukan juga dengan pengenalan dini (early warning signs) sejak debitur mengajukan permohonan kredit, karakter debitur, kelancaran pembayaran kredit, hingga penilaian prospek ekonomi dan industri. Selain itu, pedoman pelaksanaan kredit perusahaan mengharuskan adanya penerapan kualitas kredit pada sistem manajemen risiko moderen berdasarkan sistem rating Credit Risk Rating (CRR) dan juga sistem kolektibilitas BI. Upaya penyelesaian kredit bermasalah dilakukan melalui penilaian iktikad baik dan prospek usaha debitur, karena sebagai jaminan kemampuan debitur dalam memenuhi kewajibannya (repayment capacity). Kredit bermasalah umumnya disebabkan oleh kemampuan debitur dalam berbisnis rendah dan penyalahgunaan tujuan kredit. Rendahnya pengalaman pelaksana kredit, diduga menjadi salah satu penyebab rendahnya kualitas analisis dan pengawasan kredit yang dapat menimbulkan kredit bermasalah. Ekspansi kredit yang sehat harus mensyaratkan peningkatan SDM yang kompeten dan berintegritas, sehingga proses penyaluran kredit di masyarakat sesuai tujuan.
\end{abstract}

Keywords:

Kebijakan kredit bank, risiko kredit bank, profil risiko debitur, pengawasan risiko 


\section{PENDAHULUAN}

Pertumbuhan ekonomi suatu negara sangat ditentukan oleh kesehatan dari sistem perbankan di negara tersebut. Peran perbankan adalah menyediakan sistem pembayaran nasional, dimana infrastruktur dari sistem pembayaran dibawah tanggung jawab bank sentral (Ary Suta dan Musa, 2008:15; Rose dan Hudgins, 2008:8). Pada sebagian besar ekonomi, bank komersial menjadi paling dominan dalam institusiinstitusi keuangan. Bank komersial (commercial bank) menjadi sumber utama kredit bagi jutaan perusahaan, jutaan orang, keluarga, dan entitas pemerintahan (Rose dan Hudgins, 2008:3).

Sektor perbankan dapat digunakan sebagai salah satu indikator untuk melihat terjadinya suatu krisis. Beberapa faktor yang mendorong terjadinya krisis perekonomian, terutama krisis perbankan adalah lemahnya fungsi pengawasan dan pengaturan perbankan, ekspansi kredit yang tinggi dalam waktu singkat tanpa disertai analisis risiko yang menyeluruh, lemahnya struktur permodalan perbankan, dan kurangnya penerapan penilaian risiko yang berintegrasi, baik dari segi operasional, transaksi dan risiko pasar (Ary Suta dan Musa, 2008:28).

$$
\text { Perbankan di Indonesia memiliki }
$$

peranan penting bagi perekonomian. Kegagalan intermediasi keuangan dapat mengganggu proses perkembangan ekonomi (Rajaraman dan Vasishtha, 2002). Kredit di Indonesia menjadi sumber pendapatan utama bank, sehingga stabilitas bank sangat dipengaruhi oleh keberhasilan bank mengelola kredit. Jika kinerja bank komersial berhasil akan mempercepat pertumbuhan ekonomi, sedangkan jika kinerja kredit buruk akan menghambat kemajuan ekonomi dan memperburuk kemisikinan (Barth, Caprio dan Levine, 2001; Khan dan Senhadji, 2001 pada Richard, 2011:50). 
Secara historis, kinerja bank muncul dalam suatu periode yang berakhir konvensional (commercial bank) mengalami dengan ketidakmampuan debitur membayar pertumbuhan. Hal ini terlihat dari pinjaman (Groves, 1992:9). NPL merupakan membaiknya berbagai indikator perbankan seperti aset, dana, dan kredit. Pertumbuhan nilai aset perbankan sampai dengan tahun 2013 mencapai Rp 4.954.467.000.000.000. Nilai ini menunjukkan terjadi peningkatan nilai aset perbankan dari tahun sebelumnya di tahun 2012 yaitu senilai Rp 4.262.587.000.000.000. Dari sisi Dana Pihak Ketiga (DPK), tahun 2013 tercatat meningkat menjadi $\quad \mathrm{Rp}$ 1.363.062.000.000.000 dibandingkan dari tahun $2012 \quad$ sejumlah $\quad \mathrm{Rp}$ 1.353.149.000.000.000.

Kredit perbankan yang relatif baik memberikan dampak positif bagi pertumbuhan ekonomi dan bisnis nasional (tabel 1.). Di sisi lain, meningkatnya ekspansi kredit tidak semua berjalan lancar, seringkali terjadi kredit bermasalah atau non performing loan/NPL. Permasalahan kredit beban bagi rentablitas dan solvabilitas dari bank. Kinerja perbankan menunjukkan, keberhasilan melakukan restrukturisasi NPL membuat pencapaian rasio gross NPL semakin rendah.

Pada tahun 2013, rasio NPL bank umum semakin membaik yaitu $1,8 \%$ dibandingkan tahun 2012 yang tercatat senilai $2 \%$ (tabel 1.). Komposisi terbesar penyaluran kredit bank umum yaitu pada kredit modal kerja selama 3 tahun terkahir (2011-2013). Hal ini juga berdampak pada rasio NPL kredit modal kerja lebih tinggi dibandingkan rasio NPL kredit investasi dan kredit konsumsi. Namun demikian, pengelolaan NPL tahun 2013 jauh lebih dengan ditunjukkan penurunan rasio NPL pada kredit investasi, kredit konsumsi, dan kredit modal kerja. Nilai ini masih tergolong aman atau dikatakan sehat jika mengacu 
Kebijakan Dan Pengelolaan ... (Yanuar Andrianto, Moeljadi dan Andarwati)

pada kewajiban maksimum rasio NPL senilai $\quad 5 \%$.

Tabel 1.

Rasio NPL Bank Umum Perbankan di Indonesia Menurut Jenis Penggunaan tahun 2011-2013 dalam Miliar Rupiah

\begin{tabular}{||c|c|c|c|c|c||c||}
\hline \multicolumn{2}{|c|}{ Jenis Penggunaan } & 2011 & 2012 & $\%$ & 2013 & $\%$ \\
\hline \hline 1. & Modal Kerja & $1,068,676$ & $1,316,689$ & & $1,585,659$ & \\
\hline \hline & NPL & 28,279 & 28,963 & $2.2 \%$ & 31,470 & $1.98 \%$ \\
\hline \hline 2. & Investasi & 464,262 & 591,425 & & 798,157 & \\
\hline \hline & NPL & 8,917 & 10,032 & $1.7 \%$ & 13,633 & $1.7 \%$ \\
\hline \hline 3. & Konsumsi & 667,155 & 799,748 & & 909,058 & \\
\hline \hline & NPL & 10,499 & 11,600 & $1.5 \%$ & 13,176 & $1.4 \%$ \\
\hline \hline & Total Kredit & $2,200,094$ & $2,707,862$ & & $3,292,874$ & \\
\hline \hline & NPL & 47,695 & 50,595 & $1,9 \%$ & 58,279 & $1.8 \%$ \\
\hline
\end{tabular}

Sumber : Diolah peneliti dari Statistik Perbankan Indonesia (2013)

Kalangan perbankan sadar bahwa

risiko pada setiap pemberian kredit adalah kemungkinan terjadinya NPL. Faktor penyebab terjadinya NPL bervariatif, ada yang berasal dari internal bank, atau berasal dari faktor diluar bank (Groves, 1992:2; Kiryanto, 2010:8; Izzudin, 2010:13; Siamat, 360:2005; Sutojo, 1997:215). Faktor yang berasal dari internal bank pada umumnya berkaitan dengan rendahnya naluri bisnis dan atau integritas petugas bank dalam melakukan proses kredit. Adapun penyebab kredit bermasalah yang berasal dari internal debitur pada umumnya berkaitan dengan penyalahgunaan kredit tidak sesuai peruntukannya, adanya perpecahan kepengurusan usaha debitur, penggantian atau meninggalnya key person dari perusahaan debitur, dan kondisi yang berada diluar kekuasaan manusia seperti bencana alam (Rose dan Hudgins, 2005:547).

Hasil temuan lain juga (Gersbach dan Uhlig, 2006; Palazzo dan Rethel, 2008; Richard,2011; dan Waweru dan Kalani, 2009) menyatakan bahwa faktor utama penyebab NPL berasal dari pengelolaan dana 
oleh debitur untuk bisnisnya buruk, lemahnya analisa kredit, kurangnya integritas debitur, konflik kepentingan dalam organisasi bank, dan kondisi lingkungan ekonomi nasional yang kurang baik dapat menyebabkan kredit bermasalah.

Krisis perbankan jika tidak ditangani serius, dapat menurunkan tingkat kepercayaan masyarakat terhadap perbankan. Hal ini berisiko memicu terjadinya penarikan dana besar-besaran (rush) oleh masyarakat (Ary Suta dan Musa, 2008:28). Berbagai macam kasus NPL membuktikan bahwa timbulnya persoalan akibat ketidakmampuan masing-masing bank menilai mutu kelayakan kredit debitur, serta kurang memantau perkembangan kinerja kredit yang disalurkan. Memahami pentingnya pengelolaan kredit perbankan, tujuan penelitian ini untuk melakukan penelusuran secara mendalam mengenai implementasi kebijakan kredit modal kerja dan kredit investasi, serta bagaimana proses pengelolaan dan pengawasan risiko kredit yang dilakukan oleh salah satu perbankan terbesar nasional.

\section{METODE PENELITIAN}

Peneliti menggunakan pendekatan kualitatif dengan desain penelitian studi kasus untuk menganalisis secara mendalam proses pelaksanaan kebijakan dan pengelolaan risiko kredit modal kerja dan kredit investasi, menggunakan berbagai prosedur pengumpulan dan verifikasi data (Babbie, 2005:32; Creswell, 2010:20; Denzim dan Lincoln, 2011:303; Thomas, 2003:33). Beberapa asumsi yang digunakan peneliti menetapkan penggunaan pendekatan kualitatif pada penelitian ini adalah asumsi Ontological, Epistemological, Axiological, Rhetorical, dan Methodological (Creswell, 2010).

Objek penelitian ini dilakukan pada salah satu perbankan terbesar di Indonesia. 
Pemilihan objek ini didasarkan pada pengalamanan perkreditan lebih dari 50 tahun di Indonesia dan menjadi 5 bank terbaik dalam hal pertumbuhan kredit perbankan Indonesia. Mengingat peran penting kantor wilayah dan kantor cabang dalam keputusan penyaluran kredit, peneliti menetapkan lokasi (setting) yang dipilih adalah Kantor Wilayah dan Kantor Cabang di Pulau Jawa, yang merupakan salah satu kantor wilayah dan kantor cabang terbaik. Penyamaran identitas perbankan untuk menjaga kerahasiaan dan keamanan (protecting confidentiality) objek dan informan (Given, 2008;471; Lofland, et al., 2006:98).

\subsection{Prosedur Pengumpulan Data}

Peneliti menjadi sebagai instrumen penelitian (human instrument) melakukan pengambilan data penelitian pada partisipan/informan. Peneliti mengumpulkan data melalui pemeriksaan dokumen, mengobservasi perilaku, dan mewawancarai informan. Peneliti menggunakan sebuah protokol (a protocol) untuk mengumpulkan data melalui wawancara, observasi, dan dokumentasi (Creswell, 2010:271). Protokol digunakan untuk meningkatkan validitas dan reliabilitas data yang diperoleh dan sebagai panduan peneliti untuk mengungkap kejadian/peristiwa yang diperoleh selama penelitian ini berlangsung (Yin, 2009:79).

Peneliti juga menggunakan teknik triangulasi yaitu peneliti menggunakan teknik pengumpulan data yang berbeda untuk mendapatkan data dari sumber yang sama. Peneliti menggunakan wawancara mendalam dan observasi untuk sumber yang sama secara serempak dilakukan secara terus menerus sampai datanya jenuh (data saturation) atau data yang diperoleh sama dari berbagai sumber (Cooper dan Schendler, 2008:175; Given, 2008:195).

Informan (actors) dipilih secara selektif dengan 2 cara yaitu, teknik purposive 
dan penelusuran informan dengan teknik snowball, hingga tidak ditemukan variasi informasi tata kelola perkreditan (Given, 2008:798).

Teknik purposive untuk menetapkan karateristik informan sebagai sumber data agar data yang diberikan handal dan relevan. Informan yang ditetapkan adalah pimpinan di kantor wilayah, pelaksana kredit, staf analisis risiko kredit, staf administrasi kredit, staf divisi bisnis retail, dan perwakilan Bank Indonesia/OJK Wilayah. Informan tersebut memiliki kewenangan dan tanggungjawab antara lain pengambil kebijakan penetapan target kredit dan pemutus kredit modal kerja dan kredit investasi, pelaksanaan pengelolaan kredit modal kerja dan kredit investasi dengan debitur, proses penilaian kredit dan risiko, dan sebagai pengawas kredit perbankan.

Teknik snowball dalam penentuan informan, dilakukan saat peneliti mulai memasuki lapangan dan selama penelitian berlangsung. Peneliti memilih orang tertentu yang dipertimbangkan akan memberikan data yang diperlukan. Informan yang dipilih makin lama makin terarah sejalan dengan makin terarahnya fokus penelitian (Given, 2008:816). Penentuan jumlah informan pada penelitian ini ditetapkan ketika saat proses pengambilan data (collecting) sudah tidak ditemukan variasi informasi sehingga tidak perlu lagi untuk mencari informan baru (Given, 2008:798).

Document review dilakukan pada saat memulai penelitian dan dilakukan penelitian lapangan, dengan mengumpulkan dokumen-dokumen yang dimiliki oleh informan meliputi buku-buku yang relevan, peraturan-peraturan Bank Indonesia, penelitian terdahulu, peraturan internal perusahaan, kebijakan perkreditan, prosedur kredit, laporan analisa kredit, dan data-data yang relevan dengan tujuan penelitian di mengenai pengelolaan kredit modal kerja dan kredit investasi Cooper dan Emory 
(1996:357). Selain melakukan document review, peneliti juga bertindak sebagai observer (participant observation) dengan mengamati secara langsung perilaku individu dan interaksi mereka dalam setting penelitian yaitu proses pengelolaan kredit (Denzim, 2011:470; Thomas, 2003:60). Peneliti melakukan pengamatan aktivitas atau kondisi perilaku dengan analisis nonverbal (nonverbal analysis) dan analisis isi selama pengamatan (Cooper dan Emory, 1996:357).

\subsection{Teknik Analisis Data}

$$
\text { Penelitian studi kasus ini }
$$

dilaksanakan dalam bentuk penelusuruan mendalam (in-depth examination) pada proses pelaksanaan kebijakan kredit dan pengelolaan risiko kredit yang diperoleh dari wawancara dan observasi informan disertai dengan prosedur yang terstruktur (Marczyk et al, 2005:17). Peneliti melakukan transkripsi wawancara, memilah data, menyusun data ke dalam jenis-jenis yang berbeda (klasifikasi data), dan menggunakan analisis isi (content analysis) untuk melakukan analisis data. Proses content analysis mengharuskan peneliti mencari satu atau lebih komunikasi untuk menjawab pertanyaan-pertanyaan yang dibutuhkan. Keunggulan content analysis adalah satusatunya teknik yang baik untuk mengumpulkan informasi mengenai konten komunikasi (Thomas, 2003:59).

Verifikasi hasil penelitian dilakukan dengan melakukan melakukan pengecekan validitas dan reliabilitas penelitian. Validitas dikaitkan dengan pemeriksaan kebenaran/akurasi hasil penelitian menggunakan prosedur-prosedur tertentu sesuai dengan fakta yang terjadi di perbankan (Gravetter dan Forzano, 2006:138). Sementara reliabilitas mengindikasikan bahwa pendekatan yang digunakan peneliti konsisten jika diterapkan oleh peneliti-peneliti lain (Creswell, 2010:285). Strategi yang digunakan untuk 
meningkatkan kualitas data selama penelitian ini berlangsung yaitu dengan trianggulasi sumber data, member checking, perpanjangan pengamatan (prolonged time), pemeriksaan oleh sesama peneliti (peer debriefing), dan penguji independen (Creswell, 2010:286; Yin, 2009).

\section{HASIL DAN PEMBAHASAN}

Kebijakan perkreditan (credit policy) disusun sesuai dengan visi dan tujuan perusahaan yang memiliki fungsi untuk memperjelas arah dan penetapan sasaran; sebagai tolak ukur keberhasilan pencapaian sasaran; serta optimalisasi efektivitas dan efisiensi kegiatan perkreditan.

Kebijakan perkreditan disusun dengan prinsip kehati-hatian dan tetap mempertimbangkan sisi bisnis agar kredit menjadi suatu kemudahan keuangan bagi debitur memperoleh sumber pembiayaan kredit untuk aktivitas bisnisnya seperti membeli produk, bahan baku, dan aset, dan membayarnya kembali dalam jangka waktu yang ditentukan sesuai dengan perjanjian kredit Kebijakan ini mencakup panduan perkreditan, peraturan kredit, dan prosedurprosedur yang diselenggarakan untuk mendukung upaya peningkatan dan pencapaian kualitas kredit yang sehat.

$\begin{array}{rrr}\text { Kebijakan } & \text { kredit } & \text { membantu } \\ \text { manajemen } & \text { bank } & \text { untuk }\end{array}$

mengimplementasikan rencana perusahaan (corporate plan) mengenai tata kelola kredit dan memecahkan masalah-masalah (problems) yang dihadapi dalam pengelolaan risiko kredit (David, 2007:13). Manajemen bank selalu mempertimbangkan faktor-faktor risiko yang dapat membahayakan kondisi usaha bank dalam mencapai sasaran. Manajemen bank selalu memperhatikan praktik-praktik dan prinsip-prinsip perbankan yang sehat. Beberapa hal yang menjadi perhatian khusus perbankan untuk mencapai sasaran jangka panjang adalah 
pengelolaan likuiditasnya, memperkecil risiko dengan diversifikasi dan atau mengalokasikan dananya pada aset berisiko rendah, memperoleh dana dengan biaya rendah (cost of capital), dan menetukan jumlah modal dan meningkatkan modal sesuai kebutuhan.

Perusahaan induk perbankan (dalam hal ini kantor pusat) dari kantor wilayah dan kantor cabang ini mengukuhkan pendapatan terbesarnya dari pendapatan bunga sebesar 87\%. Perusahaan mempertahankan eksistensinya dan bersaing secara kompetitif di pasar bisnis perbankan nasional, terutama dalam kaitannya dengan agenda besar peningkatan dan perluasan kontribusi usaha mikro, kecil, dan menengah (UMKM) pada perekonomian nasional.

Kinerja perbankan yang relatif baik memberikan dampak positif bagi pertumbuhan ekonomi dan bisnis nasional. Secara teoritis, perkembangan ekonomi suatu negara salah satunya sangat ditentukan oleh peran serta sektor keuangan, khususnya perbankan, dalam memainkan perannya sebagai lembaga intermediasi untuk menggerakkan sektor riil.

\subsection{Kebijakan Kredit dan Manifestasi Prinsip Kehati-hatian}

Demi mewujudkan industri keuangan yang sehat sesuai arahan Bank Indonesia dan OJK, bank berperan aktif mengedepankan dan mengimplementasikan prinsip kehati-hatian pada setiap tahapan proses pemberian kredit. Prinsip kehatihatian ini dimanifestasikan pada pedoman pelaksanaan kredit bisnis retail perusahaan. Terdapat 3 (tiga) dimensi yang menjadi perhatian manajemen yaitu kebijakan pokok perkreditan, tatacara penilaian kualitas kredit, serta profesionalisme dan integritas pejabat perkreditan.

Pertama, kebijakan pokok perkreditan menekankan pada tatacara pemberian kredit sebagai upaya menjaga dan 
mengelola portofolio kredit yang sehat dalam prinsip pokok perkreditan. Prinsip-prinsip pokok tersebut meliputi pemisahan pejabat kredit, penerapan four eyes principle, penerapan risk scoring system, dan pemisahan pengelolaan kredit bermasalah. Pemisahan tanggungjawab setiap jabatan perusahaan membantu dalam fokus dalam pengelolaan, pengendalian, serta penanganan kredit modal kerja dan kredit investasi yang lancar (performing loans) dan ketika kredit bermasalah (non performing loans). Pemisahan jabatan ini juga sebagai bentuk implementasi upaya persuasif perusahaan induk dalam pengawasan para pejabat kredit di seluruh kantor wilayah dan kantor cabang di Indonesia. Prinsip pokok ini memberikan hasil pengukuran risiko kredit secara obyektif dan realistis, sehingga menghasilkan skor risiko yang dapat dijadikan sebagai dasar untuk perhitungan biaya risiko dan untuk perencanaan dan manajemen portofolio.
Pada pelaksanaan proses perkreditan, risiko tidak dapat dihindarkan dan dapat diminimalisasi dengan prosedur perkreditan yang sehat. Kantor pusat menetapkan prosedur perkreditan yang sehat agar dilaksanakan oleh seluruh kantor cabang dengan pengawasan kantor wilayah. Prosedur perkreditan yang sehat yang dimaksud adalah proses pemberian kredit yang harus mengikuti tahapan yaitu penetapan Pasar Sasaran (PS), penetapan Kriteria Risiko yang Dapat Diterima (KRD), serta penetapan Rencana Pemasaran Tahunan (RPT). Seluruh rencana aktivitas perkreditan perusahaan dengan mengedepankan prinsip kehati-hatian, terangkum dalam rencana perusahaan (corporate plan) yang mencakup alokasi sumber daya, penyusunan jadwal, dan tindakan yang diperlukan lainnya untuk mencapai sasaran perusahaan.

Kedua, penilaian kualitas kredit dilakukan untuk menghadapi risiko kredit 
bermasalah. Situasi lingkungan ekternal dan internal perbankan mengalami perkembangan signifikan, diikuti dengan kompleksnya risiko yang muncul, sehingga dibutuhkan proses pengawasan dan pengendalian kredit untuk mengelola risiko. Perusahaan menetapkan proses penilaian kualitas kredit sebagai salah satu langkah dalam penerapan prinsip kehati-hatian berdasarkan kolektibilitasnya. Penilaian tingkat kolektibilitas kredit yang sehat harus didasarkan pada 3 penilaian utama yaitu penilaian yang dilakukan terhadap prospek usaha debitur, kinerja debitur (kemampuan perolehan laba, struktur permodalan, arus kas, dan sensitivitas terhadap risiko pasar), dan kemampuan membayar debitur. Penilaian kualitas kredit berdasarkan kolektibilitas merupakan pendekatan rating secara kualitatif. Penerapan kualitas kredit pada sistem manajemen risiko moderen dilakukan berdasarkan sistem rating secara kuantitatif yang dikenal dengan Credit Risk
Rating (CRR). Penilaian kualitas kredit menggunakan dua pendekatan secara paralel yaitu sistem kolektibilitas BI dan CRR.

Ketiga, pentingnya profesionalisme dan integritas pejabat kredit akan meminimalisir risiko kredit. Etika berkaitan dengan nilai, norma, kepercayaan, dan ekspektasi yang menentukan bagaimana manusia hidup dan berinteraksi dengan budaya yang ada. Pada kasus ini, etika dikaitkan dengan tindakan pengambilan keputusan bisnis oleh pejabat kredit. Risiko non-bisnis merupakan risiko yang diakibatkan kesalahan penyaluran kredit diakibatkan oleh pelaksana kredit dan pemutus kredit. Pemutus kredit yang memiliki integritas dan profesional menjadi salah satu fungsi pengawasan dan pengendali kolektibilitas kredit debitur. Semakin berpengalaman seorang pemutus kredit disertai dengan etika yang baik, akan mempersempit kecurangan (fraud) dalam proses perkreditan dan sebagai upaya 
meminimalisasi risiko kredit. penjaringan, pengelolaan, dan pengawasan

Profesionalisme perbankan merupakan

tuntutan bagi pejabat bank dalam penguasaan kondisi usaha debitur, obyektif dari analisis/putusan setiap kredit yang diambil, kemandirian dalam mengambil sikap/putusan, pemahaman aspek legal perkreditan, dan ketertiban pelaksanaan kepatuhan terhadap peraturan mengenai perkreditan.

\subsection{Prosedur Kredit Perbankan}

Praktik prosedur pengajuan kredit modal kerja dan kredit investasi pada kantor cabang dan kantor wilayah membantu manajemen bank untuk melaksanakan standar-standar perkreditan sesuai dengan peraturan kantor pusat dan otoritas perbankan seperti Bank Indonesia dan OJK. Prosedur ini menjamin keseragaman pengambilan keputusan kredit diseluruh kantor cabang dan kantor wilayah. Adanya prinsip four eyes principle pada proses kredit dapat menjadi suatu pendekatan dalam pengawasan kewenangan para pejabat pemutus kredit dan pelaksana kredit. Kredit yang diberikan bank mengandung risiko sehingga prosedur kredit disusun untuk meminimalkan risiko yang dihadapi dalam proses pemberian kredit. Kantor wilayah memiliki tanggungjawab lebih besar daripada kantor cabang sehingga besarnya risiko yang ditanggungpun berbeda.

Kantor wilayah dan kantor cabang memiliki kewenangan melakukan penyaluran kredit modal kerja dan kredit investasi. Pelaksanaan prosedur kredit modal kerja dan kredit investasi dibedakan berdasarkan jumlah plafon kreditnya, dimana kantor cabang memiliki kewenangan untuk kredit dengan nilai kredit Rp 200.000.000 (dua ratus juta rupiah) sampai dengan $\mathrm{Rp}$ 2.000.000.0000 (dua miliar rupiah) dan pimpinan cabang dapat menjadi ketua komite pemutus kredit. Sedangkan untuk kredit 
modal kerja dan investasi dengan nilai kredit Rp 2.000.000.000 (dua miliar rupiah) sampai dengan Rp 40.000.000.000 (empat puluh miliar rupiah) akan dikelola dan diputuskan oleh komite kredit Kantor Wilayah. Hal ini menunjukkan bahwa kantor pusat membagi besaran risiko kepada setiap kantor wilayah dan kantor cabang agar meminimalisir kemungkinan terjadinya risiko non-bisnis.

Prinsip kehati-hatian juga dapat dilihat pada prosedur permohonan kredit yang diterapkan diawali dengan kewajiban calon debitur menyediakan kelengkapan dokumen menjadi syarat dasar dalam pengajuan kredit sebagai bentuk upaya pengelolaan risiko. Kelengkapan dokumen paket kredit kemudian diverifikasikasi dan diserahkan kepada pimpinan cabang setelah kelengkapan dokumen terpenuhi, untuk ditinjau. Pimpinan akan menentukan dan menunjuk salah satu pelaksana kredit sebagai penanggung jawab paket kredit calon debitur yang akan bertugas melakukan penilaian awal (prescreening) paket kredit calon debitur. Hal ini bertujuan untuk mengetahui potensi bisnis dan risiko bisnis calon debitur seperti pasar sasaran (PS) yang disyaratkan kantor pusat, kriteria risiko yang dapat diterima (KRD), jenis usaha yang dilarang dibiayai, jenis usaha yang perlu dihindari, daftar kredit macet Bank Indonesia, daftar hitam Bank Indonesia, dan daftar hitam perusahaan.

$\begin{array}{rrr}\text { Pelaksana } & \text { kredit } & \text { kemudian } \\ \text { menindaklanjuti } & \text { dengan } & \text { melakukan }\end{array}$
penggalian data calon debitur agar lebih valid dengan kunjungan ke calon debitur untuk melihat proses bisnis dan aktivitas calon debitur. Kunjungan mewajibkan pimpinan cabang dan beberapa pelaksana kredit senior (four eyes principles) untuk meningkatkan kualitas hasil pengamatan lapang (quality of observations). Laporan kunjungan (on the spot) ke calon debitur memuat informasi analisis kredit mengenai penilaian aspek non-finansial calon debitur 
seperti, aspek karakter, aspek posisi pasar bisnis calon debitur, perkembangan pasarpersaingan dan kepemimpinan, dan manajemen bisnis calon debitur. Laporan analisis paket kredit memuat informasi mengenai kesimpulan analisis tingkat risiko kredit, analisis nilai agunan calon debitur, perhitungan kebutuhan kredit, proyeksi cashflow, rekomendasi pejabat pemrakarsa (dalam hal ini pejabat pemutus kredit), syarat kredit, dan instruksi pencairan kredit.

Pimpinan kantor cabang melakukan tinjauan dokumen laporan kunjungan calon debitur, laporan analisis paket kredit calon debitur, dan laporan hasil verifikasi dokumen oleh bagian administrasi kredit. Pimpinan memiliki kewenangan untuk memutuskan paket kredit diterima atau ditolak dan menentukan besaran nilai kredit calon debitur. Penilaian dan pertimbangan utama yang seringkali digunakan dalam keputusan kredit adalah karakter calon debiur. Karakter menjadi faktor yang sangat karena dapat mempengaruhi kesungguhan dan kelancaran kredit dikemudian hari.

\subsection{Implementasi Manajemen Risiko dan Pembinaan Kredit}

Pelaksana kredit seringkali menghadapi informasi asimetris (asymmetric information) yaitu situasi dimana kreditur tidak memiliki pemahaman mengenai calon debitur sehingga keputusan yang dibuat tidak sepenuhnya akurat. Memahami hal tersebut, pentingnya manajemen risiko untuk mengidentifikasi, mengukur, memantau, dan mengendalikan risiko yang timbul dari kegiatan usaha bank (Peraturan Bank Indonesia nomor: 5/8/PBI/2003, 2003). Beberapa upaya dini untuk mengelola risiko kredit yang diterapkan oleh kantor wilayah dan kantor cabang pada penelitian ini yaitu penyaringan dan pemantauan, membangun hubungan jangka panjang dengan nasabah, komitmen pinjaman, kewajiban agunan dan saldo kompensasi, dan pembatasan kredit. 
Hal ini dilakukan agar pihak bank mengetahui informasi secara jelas, lengkap, benar, dan mendalam mengenai calon debitur untuk mengelola segala risiko yang dihadapi ketika kredit diberikan ke debitur.

Proses pengelolaan risiko (risk management process) yang dilakukan kantor wilayah dan kantor cabang mengacu pada Basel II Accord (Bank Indonesia, 2012; Kiryanto, 2011:2006). Penerapan manajemen risiko ini diawali dari kepedulian terhadap risiko (risk awareness), kemampuan mengidentifikasi risiko (risk identification), kemampuan memantau risiko (risk monitoring), dan kemampuan memitigasi risiko (risk mitigation).

Langkah pertama, kantor pusat melakukan sosialisasi yang intensif mengenai kepedulian terhadap risiko ke seluruh kantor wilayah dan kantor cabang, serta pelatihan dan pengembangan secara berkesinambungan untuk membangun budaya risiko (risk culture). Tidak cukup disitu, adanya pembagian peran dan tanggung jawab dilakukan untuk menjalankan fungsi manajemen risiko. Kantor wilayah dan kantor cabang melaksanakan pengawasan melekat dan pengawasan ganda sebagai upaya kepedulian terhadap risiko-risiko yang dihadapi dalam bisnis perbankan.

Kedua, pelaksana kredit, administrasi kredit, dan pemutus kredit (pejabat berwenang pemutus kredit) sebagai ujung tombak pendistribusian kredit diwajibkan mengumpulkan informasi mengenai jenis-jenis risiko yang berpotensi mengancam aktivitas usaha calon debitur. Setelah identifikasi dilakukan, kemudian dilakukan analisis risiko untuk untuk melihat seberapa besar probabilitas terjadinya suatu risiko dan dampak yang ditimbulkan risiko tersebut. Kantor wilayah dan kantor cabang berupaya mengelolanya dengan berbagai cara, antara lain menghindari risiko (risik avoidance), pengurangan risiko (risk 
reduction), dan pengalihan risiko (risk transfer) sesuai dengan prosedur dan aturan yang ditetapkan kantor pusat.

Ketiga, pengawasan risiko yang dilakukan kantor cabang dan kantor wilayah dapat dilakukan setelah memutuskan penanganan risiko yang tepat yaitu memantau perkembangan bisnis debitur secara rutin, baik melalui laporan kinerja usaha dan atau berkunjung ke lokasi usaha. Ketika terjadi hal yang tidak dinginkan atau timbulnya risiko kredit, maka dapat segera ditangani oleh pelaksana kredit sehingga implementasi manajemen risiko dapat berjalan efektif. Kemampuan pelaksana kredit melakukan analisis dan pengawasan usaha debitur menjadi faktor kunci untuk menyelamatkan kredit yang diberikan oleh bank.

Keempat, pengendalian risiko yang efektif adalah kemampuan bank dalam memitigasi atau mengalihkan risiko kredit yang disalurkan. Masih adanya kasus kredit bermasalah (non performing loans) merupakan salah satu contoh nyata kegagalan mengelola dan mengendalikan risiko kredit yang tidak sesuai dengan analisis dan rencana pihak bank. Pada analisis 5C, analisis watak/karakter (character) merupakan kriteria yang mutlak harus dijadikan prioritas penilaian utama. Penilaian watak/karakter calon debitur tidak mudah sehingga bank melalui pelaksana kredit harus mampu menelaah riwayat atau jejak rekam (track record) dari calon debitur. Pada kenyataanya, unsur-unsur pembentuk risiko yang umumnya sulit diprediksikan adalah seperti bencana alam, kebakaran, perubahan cuaca dan musim ekstrim, pergantian pengurus bisnis debitur ditengah jalan, huru-hara, unjuk rasa karyawan, dan sebagainya. Agunan kredit digunakan sebagai kompensasi apabila debitur mengalami gagal bayar kredit karena dapat mengurangi kerugian bank. Pembinaan dan pengawasan kredit dilakukan agar tujuan 
kredit modal kerja dan atau kredit investasi untuk mengembangkan portofolio kredit yang sehat. Kantor cabang selain melakukan langkah preventif dan represif mengelola risiko kredit sejak awal hingga pengawasan kredit oleh para pelaksana kreditnya.

Pembinaan kredit yang dilakukan kantor wilayah dan kantor cabang adalah sebagai upaya perlindungan risiko kredit dan debitur dalam mengelola bisnisnya. Pembinaan ini dapat dilakukan secara administratif (off-site) maupun pembinaan di lapangan (on-site). Fungsi administrasi kredit dan analisis kredit adalah sebagai instrumen pengawasan dan pengendalian pelaksanaan kebijakan dan peraturan perkreditan pada setiap kantor wilayah dan kantor cabang. Fungsi tersebut dapat memberikan informasi mengenai itikad baik (willingness to pay) dan kemampuan membayar (ability to pay) calon debitur untuk melunasi kembali pinjaman beserta bunganya.
Kredit bermasalah dapat diartikan suatu keadaan kredit dimana debitur sudah tidak sanggup membayar sebagian atau keseluruhan kewajibannya. Pertimbangan dasar yang digunakan kantor wilayah dan kantor cabang dalam mengidentifikasi dan mengevaluasi kesulitan-kesulitan debitur yang mengalami kredit bermasalah adalah itikad debitur dan prospek usaha debitur karena akan menjamin kemampuan debitur dalam memenuhi kewajibannya kepada bank (repayment capacity).

Penanganan kredit bermasalah bersifat antisipatif, proaktif, dan berdisiplin. Hal ini menuntut pengenalan dini (early warning signs) atas risiko kredit dan segera mengambil tindakan tepat sebelum kredit menjadi semakin bermasalah. Beberapa pendekatan yang umum dilakukan dalam upaya penyelesaian dan penyelamatan kredit bermasalah oleh kantor cabang dan kantor wilayah PT Bank $\mathrm{X}$ adalah penagihan Intensif dari debitur, rescheduling 
(penjadwalan ulang), reconditioning (persyaratan ulang), restructuring (penataan ulang), dan eksekusi agunan/jaminan kredit. Penghapusbukuan kredit dapat dilakukan apabila segala daya upaya tidak berhasil. Secara ekonomis kredit yang sudah dihapusbukukan belum seluruhnya akan menjadi kerugian riil bagi perusahaan, karena masih terdapat agunan yang dapat dijual/dilelang bahkan tidak menutup kemungkinan debitur memiliki sumbersumber keuangan lainnya yang dapat diharapkan untuk membayar kewajibannya.

\section{KESIMPULAN}

Kebijakan perkreditan tidak hanya diharapkan memperjelas arah dan penetapan sasaran (target) penyaluran kredit, namun jauh lebih penting memberikan suatu kemudahan keuangan bagi debitur memperoleh sumber pembiayaan kredit, dan mampu membayarnya kembali tepat waktu.
Kebijakan dan peraturan kredit yang disusun dengan prinsip kehati-hatian diturunkan pada prinsip pokok pemberian kredit, tata cara penilaian kualitas kredit, serta profesionalisme dan integritas pejabat perkreditan.

Analisis dan administrasi kredit merupakan instrumen pengelolaan risiko sebagai strategi preventif dan represif penanganan profil risiko kredit. Analisis kredit memprioritaskan penilaian kualitatif mengenai kelayakan debitur, karena permasalahan umum debitur adalah ketidakmampuan (inability) menyajikan data keuangan usaha. Kunjungan ke debitur (on the spot) membantu bank untuk memperoleh data lebih rinci dan meningkatkan kualitas data tentang debitur dari hasil wawancara dan pengamatan secara langsung dengan debitur, konsumen, dan atau rekanan kerja.

Rendahnya pengalaman para pelaksana kredit, diduga menjadi salah satu penyebab rendahnya kualitas analisa kredit 
Kebijakan Dan Pengelolaan ... (Yanuar Andrianto, Moeljadi dan Andarwati)

dan pengawasan (monitoring) yang

disalurkan di masyarakat sehingga

menimbulkan kredit bermasalah. Sebagian

besar disebabkan oleh kemampuan debitur

dalam berbisnis rendah dan penyalahgunaan

kredit oleh debitur.

Pertumbuhan jumlah debitur yang tidak sebanding dengan jumlah pelaksana kredit, menjadi tantangan dalam melakukan pengawasan dan pembinaan para debitur. Salah satu upaya untuk meminimalkan potensi kerugian kredit bermasalah adalah penanganan kredit bermasalah yang bersifat antisipatif, proaktif, dan berdisiplin. Hal ini membutuhkan tindakan pengenalan dini (early warning signs) oleh para pelaksana kredit, administrasi kredit, dan pimpinan cabang atas risiko kredit, sehingga dapat mengambil tindakan tepat dan segera, sebelum kredit menjadi semakin bermasalah.

Pendekatan penyelesaian kredit bermasalah didasarkan pada penilaian utama yaitu iktikad dan prospek usaha debitur, karena akan menjamin kemampuan debitur dalam memenuhi kewajibannya kepada bank (repayment capacity).

Hasil penelitian dapat digunakan sebagai evaluasi dan atau acuan (benchmark) lembaga keuangan bank dan non bank dalam melakukan tata kelola kredit yang berlandaskan prinsip kehati-hatian. Ada beberapa hasil temuan yang dapat menjadi evaluasi dalam pelaksanaan kebijakan perkreditan.

Pertama, menciptakan komunikasi dua arah (bottom-up) dengan suluruh penanggung jawab kredit harus dilakukan agar seluruh informasi mengenai perkreditan dapat tersampaikan (symmetric information) dan keputusan perkreditan dapat diputuskan dengan tepat.

Kedua, kompetensi dan integritas SDM perbankan sejalan dengan besarnya risiko kredit yang disalurkan.

Ketiga, proses pengawasan (monitoring) kinerja usaha debitur harus 
dilakukan secara intensif oleh pihak bank untuk mengetahui lebih dini potensi risiko kredit sehingga dapat mengambil tindakan lebih awal dalam penanganan kredit.

Keempat, masih rendahnya kemampuan debitur menyusun laporan keuangan menjadi perhatian khusus pihak bank. Pengukuran risiko kredit secara kuantitatif dan kualitatif harus mengakomodir debitur yang feasible but unbankable yang sebagian besar adalah Usaha Mikro, Kecil, dan Menengah (UMKM).

Keterbatasan dari penelitian ini adalah kerahasiaan data perbankan menjadi menjadi tantangan untuk memperolehnya dan mengolahnya sehingga data yang disajikan tidak merugikan dan membahayakan para informan penelitian dan industri keuangan. Data-data yang disajikan bersifat umum, sehingga peneliti melakukan trianggulasi sumber informasi agar kualitas data yang diberikan lebih mendalam dan akurat.

Kurangnya penelitian terdahulu yang sejenis menggunakan pendekatan kualitatif menuntut peneliti merancang protokol penelitian lebih rinci. Hasil penelitian juga bukan ditujukan untuk generalisasi mencerminkan kondisi pengelolaan kredit secara menyeluruh di Indonesia. Ruang lingkup pembahasan dibatasi pada pengelolaan risiko kredit dari salah satu perbankan nasional, yang penerapannya dipotret dari kantor wilayah dan kantor cabang yang ada di pulau jawa. Diharapkan adanya penelitian lanjutan yang dapat membahas delapan risiko perbankan yang ditetapkan Bank Indonesia. Selain itu, perlu memperluas cakupan objek agar dapat merepresentasikan tatakelola kredit modal kerja,investasi, dan konsumsi yang sehat. 


\section{DAFTAR PUSTAKA}

Ary Suta, I Putu Gede dan Musa, Soebowo. 2008. Membedah Krisis Perbankan; Anatomi Krisis dan Penyehatan Perbankan. Cetakan Kedua. Yayasan Sad Satria Bhakti. Jakarta.

Bank Indonesia. 2003. Peraturan Bank Indonesia Nomor 5/8/PBI/2003 Tentang Penerapan Manajemen Risiko Bagi Bank Umum. Jakarta.

Bank Indonesia. 2012. Booklet Perbankan Indonesia Edisi Tahun 2012. Jakarta.

Babbie, Earl. 2005. The Basic of Social Research. Thomson Learning, Inc. Wadsworth. Canada.

Cooper, R. Donald dan C. William Emory, 1996, Metode Penelitian Bisnis, Edisi Kelima, Jakarta, Erlangga.

Creswell, John. W. 1994. Research Design: Qualitative and Quatitative Approaches. Sage Publications, Inc.. California.

Creswell, John. W. 2010. Research Design: Pendekatan Kualitatif, Kuantitatif, dan Mixed. Pustaka Pelajar. Yogyakarta.

David, Fred R. 2007. Strategic Management; Concepts and Cases. Pearson Education, Inc. New Jersey.

Denzim, Norman K. dan Lincoln, Yvonna S. The Sage Handbook of Qualitative Research, $4^{\text {th }}$ Edition. Sage Publications, Inc. Los Angeles.

Given, Lisa M. 2008. The Sage Encyclopedia of Qualitative Research Methods; Volume 1 and 2. Sage Publications, Inc. California.

Groves, Michael. 1992. Managing Problems Loans. Toppan Co., Ltd.Tokyo.

Izzudin. 2010. Bank dan Manajemen; Cakrawala Baru Dunia Perbankan dan Manajemen. Edisi No. 113 Mei-Juni 2010. Hal: 12-16.

Kamerschen, David R. 1992. Money and Banking. $10^{\text {th }}$ Edition. South-Western Publishing. Ohio.

Kiryanto, Ryan. 2010. Bank dan Manajemen; Cakrawala Baru Dunia Perbankan dan Manajemen, Edisi No. 113 Mei-Juni 2010. Hal 8-11.

Lofland, John., Snow, David A., Anderson, Leon., dan Lofland, Lyn H. 2006. Analyzing Social Settings; A Guide to Qualitative Observation and Analysis. Thomson-Wadsworth. Toronto.

Rajaraman, I and Vasishtha, G. 2002. "Non Performing Loans of PSU Banks: Some Panel Results". Economic and Political Weekly, p. $429-435$.

Richard, Evelyn. 2011. "Factors That Cause Non- Performing Loans in Commercial Banks in Tanzania and Strategies to Resolve Them". Journal of Management Policy and Practice vol. 12(7) 2011.

Rose, Peter S. dan Hudgins, Sylvia C. 2008. Bank Management and Financial Services. $7^{\text {th }}$ Edition. International Edition. The McGraw-Hill. New York.

Siamat, Dahlan. 2005. Manajemen Lembaga Keuangan; Kebijakan Moneter dan Perbankan. Edisi Kelima. Lembaga Penerbit Fakultas Ekonomi Universitas Indonesia. Jakarta.

Sutojo, Siswanto. 1997. Manajemen Terapan Bank. Cetakan Pertama. Pustaka Binaman Pressindo. Jakarta.

Thomas, R. Murray. 2003. Blending Qualitative and Quantitative Research Methods in Theses and Dissertations. Corwin Press, Inc., New York.

Waweru, N. M and Kalani, V. M. 2009. "Commercial Banking Crises in Kenya: Causes and Remedies". African Journal of accounting, Economics, Finance and Banking Research, 4 (4), p. 12- 33.

Yin, Robert. K. 2009. Case Study Research; Design and Methods, $4^{\text {th }}$ Edition. Sage Publications, Inc. California. 